\title{
A Review of Effectiveness of Construction Waste Minimization Practices in Bauchi State, Nigeria
}

\author{
Babangida Baba ${ }^{1}$, Azeanita Binti Suratkon ${ }^{2}$ \\ ${ }^{1}$ Abubakar Tatari Ali Polytecnic \\ P. M. B. 0094, Wuntin Dada, Bauchi, Bauchi State, Nigeria \\ ${ }^{2}$ Universiti Tun Hussein Onn Malaysia \\ 101 Beg Berkunci, Parit Raja, Batu Pahat, Johor, 86400, Malaysia
}

DOI: $10.22178 /$ pos.28-6

LCC Subject Category:

TH900-915

Received 30.10.2017

Accepted 28.11.2017

Published online 30.11.2017

Corresponding Author:

Babangida Baba

babababangida10@gmail.com

(C) 2017 The Authors. This

article is licensed under a

Creative Commons

Attribution 4.0 License

(ब) (1)

\begin{abstract}
This paper reviewed the existing literature on effectiveness of construction waste minimization in Nigeria with particular interest in Bauchi State. The study highlighted the menace of construction waste to the environment. The Nigerian construction industry comprises foreign and indigenous firms which are classified into small, medium and large according to their level of capitalization and annual turnover. In the real industrialized countries, the construction industry can be responsible for up to $20 \%$ of the GDP and employs up to $12 \%$ of the total labour force. In Nigeria, the sector contributes $3.2 \%$ of GDP. This is a clear indication that construction industry in Nigeria failed to meet expectations of governments, clients and society. The material and method of this research study utilized a secondary source of data. A critical review of this recent journal articles posited new findings of effectiveness of construction waste minimization. To ascertain the actual happenings in the construction industries within and beyond the study area. The findings of this research study indicated that environmental pollution is caused by construction waste in the study area. It is also revealed that indigenous firms generate large volume of construction waste. It was evident that construction waste is ineffective to the health condition of the environment. The conclusion is drawn from the study also revealed that different approach and method should be applied to curtail and minimize construction waste effectiveness in the study area.
\end{abstract}

Keywords: construction waste; environment; effectiveness; firms and waste minimization.

\section{INTRODUCTION}

All over the world, construction industry is continually growing. This industry is mostly concerned with development of civil engineering works which include heavy infrastructural development (roads, bridges and railways etc.), residential and commercial real estate and their maintenance [16]. Factors such as migration and urbanization, arising from the demands of middle class for better living and conditions combine to give the sector this rapid growth [8]. The contribution of construction industry towards the global gross domestic product (GDP) of the developed countries revolves around $10 \%$ of their total annual budget.
The Nigerian construction industry comprises foreign and indigenous firms which are classified into small, medium and large according to their level of capitalization and annual turnover [23]. One of the largest construction firms in Nigeria is Julius Berger which has its head office in Abuja (capital city of Nigeria); other construction firms include, E. M. Mecheleti \& Sons, and Dantata \& Sawoe. In Nigeria, awarding construction contracts began in 1940s with a few foreign companies. The oil profit that followed about 10 years after independence led to an increase in need of construction and demand for construction services. The level of government interaction within the industry as regulators, purchasers and finan- 
ciers resulted in average growth rate of $18 \%$ between 2010-2012 [17]. Because of the labour intensiveness of construction services, jobs have been created and there is still potential to expand, to accommodate the rising need for service in the sector. Federal, state and local tiers of government award $70 \%$ of the contracts while the private sector award the remaining $30 \%$ of construction works this shows the scenario of Nigeria is contrary to what obtains elsewhere in the world where it is private sector drives [23]. In the real industrialized countries, the construction industry can be responsible for up to $20 \%$ of the GDP and employs up to $12 \%$ of the total labour force. In Nigeria, the sector contributes $3.2 \%$ of GDP. This is a clear indication that construction industry in Nigeria failed to meet expectations of governments, clients and society [2].

The structure of Nigerian construction industry is complex having different types of clients and contractors. This consist of public and private clients, main contractors and sub-contractors, indigenous and foreign companies, low technology firms and sophisticated specialists, builders and civil engineers and a whole range of construction professionals connected within the industry. The major divisions in the industry are building construction division and civil or heavy engineering construction division.

The federal government of Nigeria involves in most of the complex projects such as road, sea and air port and some heavy engineering projects at about $64.9 \%$ of the project executed. This is followed by state government which is responsible for about $22.7 \%$ of the projects in the industry, although there is still some form of partnering with different groups of investors in the industry [14].

The Nigerian construction industry continues to be the major stimulant in the country's economic growth and development. This strong interrelationship between the economy and the construction industry further strengthens the need to ensure that project planning and management are cost-effective [5]. But experience has shown that excessive project cost and time overruns have been all too evident involving works undertaken by both the indigenous and foreign contractors [7]. These were due to design errors, unexpected site conditions, increasing project scope, weather conditions and other project changes. It is also evident that those contractors who perform and deliver their earlier projects successfully fails to deliver similar projects in future and facing time and cost overrun. In view of this, the iron triangle (on time, under budget, according to specifications) which has been widely accepted criteria for project successful and economic delivery during the last couple of years in the Nigerian construction industry can no longer be the sole determinant of project successful and economic delivery criteria due to changes in demands of users, evolving environmental regulations, shifting functions of projects, the inherent risks and the inhibiting risk factors associated with construction projects. Throughout the world, construction industry like many other industries is being transformed to meet the new demands of the twenty-first century [9]. As the business environment within which the construction organizations or companies operate continues to change rapidly. In spite, many changes which have affected construction industries world-wide, the structure of the Nigerian construction industry in terms of its operations has remained largely unaltered. Hence organizations or companies that fail to adapt and respond to the complexity of the new business environment tend to experience survival problems [14].

Conceptual evidence revealed that Julius Berger Nigeria Plc is the leader in the Nigerian construction industry, as it controls a large chunk of public sector construction work in the industry. With the entrance of Chinese construction giants into the Nigerian construction industry, the dominance of Julius Berger Company began to face significant threat in the long term. The growing popularity of Public Private Partnership (PPPs) also means more international construction firms are likely to come into the Nigerian construction industry as observed by [15].

\section{MATERIALS AND METHODS}

It was conventional and accepted ways of data collection that is qualitative and quantitative. The former entails interview with designated respondents, focus group discussion, ethnography and personal observation. The latter, comprises structure questionnaires as survey instrument. The method of data collection of this research study is secondary sources which comprises journal articles, textbooks, newspapers, statutory documents. Critical review of this recent journal articles posited new findings of effectiveness of construction waste minimization. Different sources give account of this phenomena in Nigeria with special consideration of Bauchi State. Content analysis of these documents was carried out. 


\section{RESULTS AND DISCUSSION}

From the literatures highlighted above the construction waste minimization is a very vital issues that professional in Nigeria were concerned about $[18,19]$. It was evident that waste minimization in the country is a recent government concern where many construction were summoned to show case their method used in minimizing their construction site with waste as [2], many organisation and building firms operates under the jurisdiction of government and accept the process and procedure of waste minimization in construction sites [13]. According to [20] and [22], it was disagree that the findings of [12], that waste minimization in construction site can reduce environmental hazard posted by neighbourhood but this assertion is contradicted $[6,10]$, because recent research conducted in many States of the federation agree that construction site waste can cause diseases to the environment $[1,11]$. It is agree that environment is polluted by waste generated from construction sites in many cities in Nigeria [21], but [4] in their study stressed that environmental pollution is cause majorly by other household and industrial waste, even though, construction waste make large volume of this garbage. Similarly, studies have contributed to the main area of concerned in minimizing construction waste in many part of Nigeria most especially Bauchi State.

\section{CONCLUSION}

Generally, previous researches highlighted the problem of construction waste to the environment, and specifically, pollution is characteristic of many construction and industrial site. It is evident that waste generated from construction of small and large project are not monitored properly. The study concluded that many obstacles in construction are caused because of large waste generation. It was also concluded that the benefits of clearing construction waste are thereafter compared to the land filling (waste management) in each of the sites to regulate the option that best fit the sites in an environmentally sustainable manner. The study shows that construction waste is ineffective to the health condition of the environment. Conclusion drawn from the study also revealed that different approach and method should be applied to curtail and minimize construction waste effectiveness in the study area.

\section{ACKNOWLEDGEMENT}

The author wishes to extend his gratitude to his supervisor for constructive and technical suggestion given to him which sharpen his way of conducting the research. He will also show his appreciation to his employer ATAP, Bauchi for the sponsorship given to him which enable him further his study in UTHM.

\section{REFERENCES}

1. Adeagbo, D., \& Kunya, S. (2005). Review on waste reduction strategies on Nigerian construction site. ATBU Journal of Environmental Technology, 2(1), 49-55.

2. Adeniyi, T. (2017, October 23). Abuja to host waste management summit. Daily Trust. Retrieved from https://www.dailytrust.com.ng/abuja-to-host-waste-management-summit.html

3. Akinkurolere, O. O., Aribisala, J. O., Oke, O. L., \& Ogundipe, O. M. (2013). Construction waste recycling in sustainable engineering infrastructural development. International Journal of Development and Sustainability, 2(2), 1066-1074.

4. Ayodele, T. R., Ogunjuyigbe, A. S. O., \& Alao, M. A. (2017). Life cycle assessment of waste-to-energy (WtE) technologies for electricity generation using municipal solid waste in Nigeria. Applied Energy, 201, 200-218. doi: 10.1016/j.apenergy.2017.05.097

5. Babatunde, O. K., \& Low, S. P. (2013). Chinese construction firms in the Nigerian construction industry. Habitat International, 40, 18-24. doi: 10.1016/j.habitatint.2013.01.002

6. Demirbas, A. (2011). Waste management, waste resource facilities and waste conversion processes. Energy Conversion and Management, 52(2), 1280-1287. doi: 10.1016/j.enconman.2010.09.025

7. Eastman, C. M., Eastman, C., Teicholz, P., Sacks, R., \& Liston, K. (2011). BIM handbook: A guide to building information modeling for owners, managers, designers, engineers and contractors. Hoboken: Wiley. 
8. Esa, M. R., Halog, A., \& Rigamonti, L. (2017). Strategies for minimizing construction and demolition wastes in Malaysia. Resources, Conservation and Recycling, 120, 219-229. doi:

10.1016/j.resconrec.2016.12.014

9. Hawken, P., Lovins, A. B., \& Lovins, L. H. (1999). Natural capitalism creating the next industrial revolution. New York: Little, Brown and Company.

10. Hossain, M. U., Wu, Z., \& Poon, C. S. (2017). Comparative environmental evaluation of construction waste management through different waste sorting systems in Hong Kong. Waste Management, 69, 325-335. doi: 10.1016/j.wasman.2017.07.043

11. Idris, I., Sani, A., \& Abubakar, A. (2015). An Evaluation of Material Waste and Supply Practice on Construction Sites in Nigeria. Journal of Multidisciplinary Engineering Science and Technology, 2(5), 1142-1147.

12. Leshinsky, R. (2012). Use of planning agreements to support sustainability and environmental preservation. International Journal of Law in the Built Environment, 4(2), 157-172. doi: 10.1108/17561451211242521

13. Madawaki, A. (2012). Adoption of International Financial Reporting Standards in Developing Countries: The Case of Nigeria. International Journal of Business and Management, 7(3). doi: 10.5539/ijbm.v7n3p152

14. Mudi, A., Bioku, J. ., \& Kolawole, O. (2015). Assessing the Characteristics of Nigerian Construction Industry in Infrastructure Development. International Journal of Engineering Research \& Technology, 4(11), 546-555.

15. Odediran, S. J., Adeyinka, B. F., Opatunji, O. A., \& Morakinyo, K. O. (2012). Business structure of indigenous firm in the Nigerian construction industry. International Journal of Business Research and Management, 3(5), 255-264.

16. Oladinrin, T., Ogunsemi, D., \& Aje, I. (2012). Role of Construction Sector in Economic Growth: Empirical Evidence from Nigeria. FUTY Journal of the Environment, 7(1). doi: 10.4314/fje.v7i1.4

17. Olubomehin, O. O. (2016). The development of national trunk roads in Nigeria, 1960 - 2013. Lagos Historical Review, 15(1), 1. doi: 10.4314/lhr.v15i1.1

18. Oluwakiyesi, T. (2011, May 27). Construction Industry Report. A Haven of Opportunities. Retrieved from

https://www.proshareng.com/admin/upload/reports/VetivResearchConstructioSectorReport May2011.pdf

19. Onifade O. A. \& Nwabotu F. A. (2014). Implications and causes of illegal refuse dumps in Ilorin South local government area, Kwara State. Arabian Journal of Business and Management Review, $4(2), 148-155$.

20. Oteng-Ababio, M. (2014). Rethinking waste as a resource: insights from a low-income community in Accra, Ghana. City, Territory and Architecture, 1(1), 10. doi: 10.1186/2195-2701-1-10

21. Somorin, T. O., Adesola, S., \& Kolawole, A. (2017). State-level assessment of the waste-to-energy potential (via incineration) of municipal solid wastes in Nigeria. Journal of Cleaner Production, 164, 804-815. doi: 10.1016/j.jclepro.2017.06.228

22. Soutsos, M. N., Tang, K., \& Millard, S. G. (2011). Use of recycled demolition aggregate in precast products, phase II: Concrete paving blocks. Construction and Building Materials, 25(7), 31313143. doi: 10.1016/j.conbuildmat.2010.12.024

23. Wahab, A., \& Lawal, A. (2011). An evaluation of waste control measures in construction industry in Nigeria. African Journal of Environmental Science and Technology, 5(3), 246-254. 